Mercator, Fortaleza, v. 16, e16005, 2017.

DOI: https://doi.org/10.4215/rm2017.e16005

ISSN: 1984-2201

Copyright @ 2002, Universidade Federal do Ceará

\title{
CHALLENGES AND PERSPECTIVES OF SECOND-GENERATION CLUSTERS
}

\author{
VIEIRA, Jeferson de Castro ${ }^{\text {* }}$
}

(a) Phd in Social Science. Lecteur Pontifical Catholic University of Goiás (PUC-GO). http://lattes.cnpq.br/0972106177221533

\section{(*) CORRESPONDING AUTHOR}

Address: PUC-GO - Praça Universitária, 1440, CEP: 74605010 - Goiânia (GO), Brasil. Tel: (+55 62) 39461151. E-mail: jcastrovieira@gmail.com

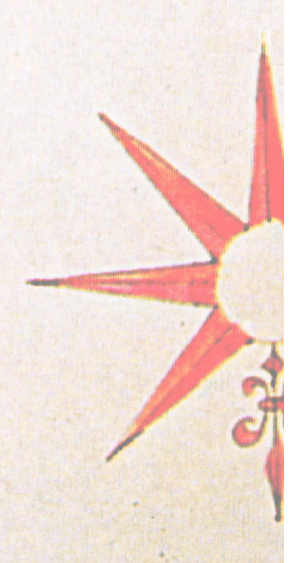

\begin{abstract}
This article analyzes the policies in support of local productive arrangements (APLs) in Brazil and delineate the prospectives for a new generation of APLs considering the National Plan for Regional Development. The analysis is based on literary revisit the productive agglomeration theory from the perspective of innovation. Makes an examination of APLs policy experiences in Brazil. Presents the second generation of APLs with their methodological reformulations in a regional development context. The paper concludes that the debate on the second generation of policies for APLs opens a large field of research and empirical studies for a profound evaluation of the relationship between the local and the regional.
\end{abstract}

Keywords: Local Productive Arrangement; Second Generation of APLs; Regional Development; Planning; Territory; JEL Classification: 010, 020, R10, H70.

\section{RESUMO/ RESUMEN}

\section{DESAFIOS E PERSPECTIVAS DOS APLS DE SEGUNDA GERAÇÃO}

Este artigo analisa as políticas de apoio aos arranjos produtivos locais no Brasil e traça as perspectivas de uma nova geração de APLs tendo em vista o Plano Nacional de Desenvolvimento Regional. A análise baseia-se em um revisita literária da teoria de aglomeração produtiva sob o olhar da inovação. Faz um balanço das experiências de políticas de APLs no Brasil. Apresenta a segunda geração de APLs com suas reformulações metodológicas em um contexto de desenvolvimento regional. O trabalho conclui que o debate sobre a segunda geração de políticas para APLs abre um grande campo de pesquisa e de estudos empíricos para avaliar com mais profundidade a relação entre o local e o regional.

Palavras-chave: Arranjo Produtivo Local; Segunda Geração de APLs; Desenvolvimento Regional; Planejamento; Território; Classificação JEL: 010, 020, R10, H70.

\section{DESAFÍOS E PERSPECTIVAS DE LA DE SEGUNDA GENERACIÓN DE APLS}

Este artículo analiza las políticas de apoyo a los arreglos productivos locales (APLs) en Brasil y se esboza las perspectivas de una nueva generación de APLs tenendo en vista el Plan Nacional de Desarrollo Regional. El análisis se basa en una revisita literaria de la teoria de la aglomeración productiva desde la perspectiva de la innovación. Se hace un balance de las experiencias de políticas de APLs en Brasil. Presenta la segunda generación de APLs con sus reformulaciones metodológicas en un contexto de desarrollo regional. El documento concluye que el debate sobre la segunda generación de políticas para los APLs engendra un amplio campo de investigación y estudios empíricos para evaluar más a fondo la relación entre los niveles locales y regionales.

Palabras clave: Arreglo Productivo Local; Segunda Generación de APLs; Desarrolo Regional; Planeamineto; Territorio; Classificación JEL: 010, 020, R10, H70. 


\section{INTRODUCTION}

This article aims to analyze the regional dimension of development, especially the local productive arrangements. The purpose is to understand the relationships between Local Productive Arrangements (APLs) and regional development. The hypothesis of this paper is that the policies carried out by the first generation of local productive arrangements have been exhausted because they embrace distinct political, social and economic interests, and at times competitors, and this arrangement did not constitute a true systemic policy of regional development.

This fact to a series of inquiries. Whither, has the APL policy had the necessary tools to overcome resistance and fulfill the intended integration mission? Can their difficulties be attributed to conception problems or to a discrepancy between formulation and implementation? How effective are the channels of dialogue and coordination provided by the National Regional Development Plan (PNDR)? What expertise can be inferred to drive the second generation of APLs?

It is worth mentioning that although development issue is part of economic concerns since the classical economists, with a vast literature that seeks to explain the development of regions, states, and nations, the concern on the screen is to make a snippet of the importance of APLs for regional development. Thus, it presents the concept of APL-developed in Brazil by RedeSist (Research Network on Productive Systems and Local Innovation), under the coordination of numerous papers written by José Eduardo Cassiolato and Helena M. M. Lastres. This concept based on an evolutionary view on innovation and technological change, which identifies with the concerns of geographical concentration of productive activities and the systematic relationship between companies, governments, institutions of higher education and research and non-governmental entities.

In this manner, recent researches and debates on policies to support APLs implemented in the different units of the Federation, over the last decade, point to the need for a new generation of policies for APLs, since their methodological formulations, concept, and constituent elements were not be deeply analyzed. In this way, the proposal of the second generation of APLs disclosure opportunities for the use of concepts and indicators that are capable of integrating national, regional and local development priorities in a systemic way, promoting the strengthening of productive and innovative capacities.

\section{REVIEWING THE THEORY OF PRODUCTIVE AGGLOMERATION UNDER THE INNOVATION PERSPECTIVE}

The debate about the understanding of the different theoretical-conceptual trajectories of the processes of acquisition and use of knowledge, of the productive and innovative capacities generated and developed, reinforces the importance of revisiting the theories of productive agglomeration. More and more resources demonstrate that stimulating business competitiveness involves understanding the mechanisms of creation, incorporation, improvement and accumulation of skills and knowledge that are explicitly associated to local production processes. This implies that we must comprehend how productive and innovative capacities are generated and spread more easily in some environments than in others.

The starting point in the economic literature to address the formation of industrial agglomerations (industrial district) should be sought in Marshall (1985). He deals with the interaction between small and large companies, describing the small companies aggregated regionally and operating in the same productive sector, as a way to obtain economies of scale previously only accessible to large companies. This implies that a considerable part of capital consists of knowledge and organization. 
In this way, an important source of external economies is precisely the localization of companies, especially the concentration of many similar small businesses in the same region.

In this manner, what matters most for regional and local development is the establishment of productive agglomerations, their spatial dimension, and the attempt to understand the reasons that lead to the emergence of agglomerations of efficient and competitive companies in certain specific localities. This can be confirmed in the analyses of productive agglomerations presented as typologies by Storper (1997) and Porter (1986), which deal with the industrial district of Marshall (Italian experience), industrial district established by state (very common in Brazil), satellite platform (Chinese export processing zone) and cluster (Silicon Valley in the USA). What is common among these typologies is a concern with territorialization, in which the geographical proximity of companies and institutional actors generate positive externalities for the region.

In this context, the financialization of wealth posed by Chesnais (1996) starts a debate about the development of skills and innovations at national and international borders. As the process of mundialization of wealth is socially and regionally exclusionary, countries need alternative policies to splay their economic territories. Therefore, productive agglomerations presented as one of the possibilities of regional development in search of a reduction of the dependence of exogenous factors, of creating its own identity.

In this sense, Schmitz (2005) presents the concept of "collective efficiency" as a competitive advantage derived from local external economies. The World Bank (2000) draws attention to two combined phenomena - globalization and localization. This demonstrates, according to the Bank, that localization requires cooperation between cities, regions, and local communities. In this relation, the importance of social capital emphasized: networks of trust and association for sustainable development. Corroborating with this thesis, it noticed in Corò (2002), which highlights the growth of competitive pressures arising from globalization, productive relations, and markets, where the competitiveness of agglomerations depends on the ability to respond to external stimuli without losing their own identity. This brings as a corollary that the ability to potentiate a given agglomeration necessarily passes through the generation, diffusion and use of knowledge in an articulated and collective way.

In this conception the learning process formation, Johnson and Lundvall (2001) emphasize that the learning economy is not necessarily a high-tech economy. Learning is an activity that occurs in all areas of the economy, including the so-called low-tech and traditional sectors. This means that low-income countries and regions affected by the learning economy with the same intensity and, to some extent, feel the need to develop collective skills even more intensively than the more developed metropolises on the planet.

From this argument, the network economy approach in Castells (1999) calls for attention, involving the social capacity to cooperate and to communicate with different types of individuals and specialists, which embedded in regions and organizations. This author presents that shared routines, common codes for communication and the formation of social relationships within teams can be considered as different ways of incorporating know-how into collective units. This reinforces the thesis that innovation success is greatest when the strategy used by companies/regions combine intense networking work with customers, suppliers and knowledge institutions.

With this in mind, topics such as geographical proximity, global communication networks and the globalization of product markets are progressing basically in four lines of research: new economic geography (innovative activities tend to clump because of spillovers of knowledge); business economics (competitive advantage derived from local factors); regional science (industrial districts); and literature on innovation (interaction learning, innovation systems). Given these lines of research and working in the policy-making arena, Cassiolato and Lastres (1999) focus on the communities in which it is possible to observe the actors operating in a concrete context of organizations and institutions for the construction of capacities, obtaining true change techniques and innovations. 
There is, therefore, a clear understanding that innovation is a process of search and learning, socially determined and influenced by institutional and organizational formats. In this innovative process, these authors accentuate the importance of using concepts that emphasize regional and local aspects such as learning, interactions, competencies, complementarities, selection and path dependence, in which scientific and technological knowledge follow a historical cumulative process, which sets new paths for local and regional changes.

In this context, the formulation of the concept of APL and the National Innovation System (SNI) will be based on the evolutionary literature, neoschumpeterian (FREEMAN, 1987; LUNDVALL, 1988; NELSON, 1983). These concepts part of the premise defended by Schumpeter (1982) that technological change is the engine of capitalist development, where the firm is the locus of action of the innovative entrepreneur and the development of technological innovations. There is an emphasis in this literature on processes of learning and innovation, with highlighting on the spatial issue. Thus, the SNI concept acquires considerable importance in the literature on innovation and the conception of public policies. Therefore, SNI involves networks of institutions supporting R\&D activities, networks of relationships between firms, existing relationships between users and suppliers of the various products, governmental incentive structures, and educational systems.

In effect, the concept of local productive arrangement (APL) was practically developed in the late 1990s by the Network of Research in Arrangements and Production Systems and Local Innovation (RedeSist). The APL focuses on a specific set of spatially localized and sectorally specialized economic activities geared to the generation and diffusion of new products and processes, combining elements of the evolutionary referential and neoschumpeterian vision of innovation systems with contributions on the development of the Latin American structuralism theories (Lastres, 2007). Therefore, the focus on productive arrangements based on a systemic view of productive and innovative activity, considering a multiplicity of economic, political and social actors that aim to promote regional and local development.

So, as an analytical framework, the concept of APLs is associated with the spatial agglomeration of economic, political and social agents involved in a specific set of productive activities in which structures of links and relationships of interdependence. In this aspect, the methodological approach of the APLs emphasizes the central role of innovation and interactive learning as factors of sustained competitiveness (CASSIOLATO; LASTRES, 2003). In this analytical perspective, particular emphasis placed on the investigation of learning, cooperation and innovation processes occurring in specific geographic spaces.

Thus, the conceptual proposal of the APL, built and led by Lastres and Cassiolato (2008), is established as a new view of the economic space that takes into account the regional and local specificities of those who work in productive activities. Without neglecting the space for national policies, these authors seek to strengthen the localized and contextual nature of learning, shedding light on the systemic nature of innovation and the mediating role of territories in the face of complex social relations. It is, therefore, a perspective that rejects taxonomies and decontextualized policy models of local and regional development.

\section{A BALANCE OF APL'S EXPERIENCES IN BRAZIL}

Since the 1990s, programs to support productive agglomerations and stimulate local vocations are adopted throughout the Country, leading to the wide dissemination of experiences of this nature. Treated, sometimes, as an alternative to regional development, this set of initiatives presents, however, the absence of a comprehensive national policy that provides direction and meaning to the autochthonous experiences that are accumulating. In Brazil, there is the internalization of the theoretical reference of APLs in programs to support productive activities in several States. 
Thus, since 1999, public policies designed to develop APLs are officially part of the governmental agenda. The APLs incorporated by the Ministry of Science and Technology and strengthen with its inclusion in the Federal Government Plans (PPA 2004-2007; PPA 2008-2011) and mainly by the establishment of the Permanent Working Group for Local Productive Arrangements (GTP APL), in 2004, with the participation of several federal cabinets, federal banks, confederations, teaching and research institutions and state governments.

In this context, Apolinário and Silva (2010) closely list a growing movement of popularization of the term local productive arrangements, of construction of the concept in the country, a process that would be driven by previous debates around initiatives such as technological platforms, industrial districts, support for micro and small enterprises (SMEs), DLIS and competitiveness forums, among others. Lastres and Cassiolato (2008) have a similar understanding, pointing out that the term APL starts to replace other supposed analogs, in a process of standardization of terminologies perceived by the political agents as a contribution to the efforts of articulation of actions and improvement of effectiveness. Therefore, the APL concept would present advantages by being an integrated perspective, resulting in a new way of capturing, understanding and guiding productive development, while expressions such as industrial district, agglomerations, clusters, etc., would include normative ambitions mutually rejected.

In this way, the policy of APLs contemplates in its scope strategies of promotion and regional and local development, with ample possibilities of expansion of income, jobs, and innovation. The role of the Permanent Working Group was decisive for the evolution of the institutions' views on the subject. Thus, there was the identification of existing APLs in the country, the definition of joint actions between governments and participants in the arrangements, proposals for multisector management models, construction of an information system for the management of actions and elaboration of terms of reference with conceptual and methodological aspects.

In addition, as a way to test the methodology of integrated performance, decompose of the APLs made, in which it sought to detect the arrangements to prioritize. In this context, partnerships with the State Support Groups for Local Productive Arrangements were fundamental in the analyses and institutional articulations with a point of view to the planning and execution of the development plans of each APL. There was, in theory, an effort of joint action between the State Nucleus and the GTP APL, that all participants in arrangements would have a coordinated, articulated and full performance in the APLs. This implied developing the necessary institutional framework for a true APL policy in Brazil.

In order to have a dimension of the APLs in Brazil, in 2004, the GTP APL consolidated its first survey of existing productive arrangements in the Country, achieving 460 experiences. The following year, with the support of 37 governmental and non-governmental, federal and state institutions, a new survey identified 957 arrangements. In 2011, the GTP APL focused its work on 267 priority APLs, indicated by the State Support Centers. Between 2009 and 2010, Redesist researchers conducted the most comprehensive study ever conducted in Brazil on local productive arrangements. The survey entitled - "Mapping and analysis of policies for local productive arrangements in Brazil" - carried out in twenty-two units of the Federation with resources from the National Bank for Economic and Social Development (BNDES), which resulted in the publication RedeSist / BNDES. In this publication, the points that deserve mention in relation to the block of states of the South Center of the country are the following:

i) In the case of Rio Grande do Sul, the program was included in the state public budget and its articulation with state industrial and regional development policies. But such policy has not kept clear strategic dimension in government management that implemented, with a gradual reduction in the use of it as a tool towards a policy of supporting local demands; 
ii) In the experience of Santa Catarina, they were unable to articulate the APL policy with state policies of regional and productive development that represented a strategic government action. Therefore, there was no movement towards the use of this policy instrument to a local and productive development strategy;

iii) In the case of Paraná, the institutional arrangement created was efficient to incorporate the concept of APL in the scope of institutional actions and to disseminate it within the productive activity. However, on a corresponding step to the implementation of APL policies were weak to implement medium and long-term coordinated policies;

iv) In the State of São Paulo, the APLs promotion program was incorporated as part of the integrated local development strategy;

v) In the experience of Minas Gerais, the politics of support to APLs characterized as restricted from the sectoral, spatial point of view and of the structures contemplated in few arrangements. Sectorial policies, centered on several secretariats, should be more articulated with policies for APLs. There is no room for the separation of sectorial policies and policy for APLs. There is no usage of APLs policy in coordination with regional development policy;

vi) In the case of Rio de Janeiro, actions to support APLs were structured in a bureaucratic way, circumscribing them to the definition of objectives and goals, but rarely articulating to a structured regional planning. APLs took a compensatory character in the regional development plan;

vii) In the State of Espírito Santo, there was no convergence of actions and methodologies by the agencies. In fact, it can be characterized as a reactive nature of the state facing the demands of federal agencies and enterprises;

viii) In the experience of Mato Grosso do Sul, although the state government has a long history of regional planning, the policy for APLs inserted through stimuli offered by the federal government. There was no more effective integration of APL policy within the framework of territorial development policy;

ix) In the case of Goiás, despite supporting segments and territories relegated by traditional policies, it was limited to take a role of compensatory policy;

$\mathrm{x})$ The paper concludes that in these experiments there are common limitations in the operationalization of the state policies for APLs, which result from a deficiency of institutional framework that serves as a basis for the adoption of this type of policy (CAMPOS et al., 2010, p. 48-54).

Obviously, such limitations reflected in the lack of articulation between the instruments of support adopted in the different spheres of government, the lack of convergence amid the support actions adopted in the States and the general orientation of the productive development policy of the federal government. Even so, there is recognition of the advances made by the implementation of the policies of APLs in its first generation (traditional APLs), of a collective learning with the incorporation of several actors, activities and regions as a collaborative strategy for regional development in Brazil.

In this regard, APL policies recognized as an active "epistemic community", described by Haas (1997), as networks of professionals with experience and competence in certain fields of knowledge and intellectual authority in specific policies. That acquires great influence on policy makers in the era of globalization, promoting the approach of issues in national and international agendas, putting decision makers under the challenge of understanding such congruence to succeed in their domestic goals. In this aspect, it can be evidenced that APL policies, because they are capable of articulating present cause and effect relationships to complex problems, should be treated 
as epistemic communities that provide prosperous interpretations of new scenarios and addition processes of regional development.

In this line of reasoning, Caporali (2011) recognizes that the policy developed by the APLs was decisive for the search for elementary gains of competitiveness, but that needs a more appropriate study, including a policy of reaction to the deindustrialization tendencies in course in Brazil. In this same direction, Lastres (2011) draws attention to the policies of APLs that played a decisive role in overcoming specific policies developed that could not see that the true productive development passes through the interaction between actors of the same chain and its articulations with economic, political and social actors.

As a mediation to analyze APLs policies, Brandão (2011) draws the attention of the PPA (Plurennial Plan) as an important planning tool - an advance of the 1988 Constitution - in which the commitment to the regional question were reaffirmed in the new Charter. The need for regional planning spelled out in the constitutional text, referring to the complementary legislation defining the conditions, organizations and plans for regional development. However, Brandão (2011) recognizes that although the PPA represents an advance, it affirms that there are limitations imposed by the economic conjuncture. Therefore, the "budget-makers" gained ground on the strategic issues of the country's development and planning.

This may be an interesting clue to evaluate the reason for the PPAs to incorporate APL policies, but to translate into a true regional development policy since the budgetary logic must not overdimension the other actions. Brandão (2011) argues that budget logic and that sectorial and conservative interests do not allow structural actions to advance, important guidelines for public action in their spatial dimension are abandoned.

In addition to the budgetary issue that stands out from the regional planning, there are a number of criticisms made to policies to support first generation or traditional APLs in Brazil, where the most persistent refer to an alleged administrative and/or localistic view of this policy. Administratively, it reduces politics to a question mainly related to administration, management or governance of APL with reference to successful cases, in general, more developed regions and thus often decontextualized from the local reality.

This lack of contextualization portrayed as a serious problem because it deals with policies whose focus is the resolution of the problems of social and regional imbalance. Thus, it can stated that:

The continuous adoption of models inspired in more developed regions ends up having application always restricted to those parts of the country whose conditions most closely approximate the model used. An unsurprising result of this policy generation is precisely the reinforcement of such imbalances (LASTRES et al., 2010, p.439).

In the question of APL being local, there is a debate about the possibilities of local scale creating its own conditions of dynamism. The confrontation with "localisms" in contemporary public literature and politics became predominant in the theoretical discussion on development in its spatial dimension (local, territorial, urban and regional). Thus, a critique of the mechanistic and indiscriminate way were perceived, without considering the specificities of a continental Brazil, diverse and heterogeneous, in which the public policies are elaborated and implemented. In this sense, the main criticism that characterizes much of the debate on regional and local development is an exaggerated endogeny that trivializes concepts and overvalues capacities while at the same time consecrating categories and notions distant from the critical perspective of society. It is, therefore:

An exaggerated endogeny of localities that faithfully believes in the capacity of the wills and initiatives of the actors of an entrepreneurial and supportive community, that has control over its destiny and seeks 
to promote a virtuous and dependable governance [...] In this context, 'locality can do everything', and in view of the growing 'sensitivity of capital to local variations', it would suffice to show itself to be different and 'special', propagating its comparative advantages of competitiveness, efficiency, amenities, etc. to have guaranteed their inclusion in modernity. This struggle of places to achieve the best 'sale of the region or city', with the unrestrained pursuit of attractiveness of new investments, improving the 'local business climate', subsidizing the tributary, logistic, land and wage costs of the enterprises, has [...] challenged the discussion of real structural development issues (BRANDÃO, 2007, p. 35-37).

The enormous paradox pointed out by Brandão in these formulations resides in the imprecise treatment given to the local space. The theme localism gained relevance during the 1990s when it was hosted by numerous public and private institutions. The governmental orientation of the period and the lack of prestige of the traditional regional policy instruments end up elevating localism to the alternative of development for depressed territories and even facing the historically consolidated regional imbalances. Thus, according to Brandão (2003), an excessive valorization of the territoriality of the process of economic development that proclaims the disappearance of intermediate scales between local space and the globalized economy. In this sense, the Brazilian macro-institutional configuration points to a scenario of fragile articulations between the national, state and local scales, denouncing the gravity of the crisis of the federal pact.

According to Affonso and Silva (1995), the federative pact consists of an intricate system of exchanges, most often implicated, centered largely on public funds and responsible for soldering regional interests and for the constitution of a national space of power. In recent years, disintegrating centrifugal forces, both internal and external to the national space, have acted to problematize this federative pact and make it difficult to recompose it to new bases. This translates into federalism crisis, which is a fundamental dimension of the crisis of the state. The reference to the spatial dimension of the crisis is mainly in a country marked by such large regional disparities. Along the same line of reasoning, Costa (2010) adds that two major processes have emerged in most Latin American nations within the framework of the new historical milestone in which devaluation of planning, and sectoral and regional policies and decentralization to alienate national state responsibilities that could allegedly met by sub-national levels.

In this direction, a question that remains open is what were the contributions of the endogenous development of first generation APL policies in the absence of a national and regional policy of development and land use planning? In spite of the numerous problems presented by the Brazilian agglomerations, which are usually just agglomerations of companies, or that did not have an effective link with the regional development, therefore, not consolidating as a true APL in its theoretical conceptualization.

In this matter, it can be stated that the APLs, as an instrument of economic policy aimed at regional development, although not in an organic, systemic way, have given their contributions. Costa (2010, p. 165) reports some important subsidies: the development of microregional vocations; adding value to products and verticalization of production; diversification of the production base and the export agenda; progress in the indicator of social inclusion by improving the quality of employment, raising wages, improving the technical qualification of labor and, consequently, reducing social inequality; increasing in the regional internal market; gestation of a sustained process of growth through the endogenization of some of the key variables, the integration of the regional economic space and support for changes in the regional socioeconomic structure; and social capital development, the governance capacity of local actors and fostering the construction of a territorial pact with the development. 


\section{SECOND GENERATION OF POLICIES FOR APLS}

In the light of these considerations, it can be pointed out that there is room for formulating development policies at different geographic scales (national, regional, state, territorial and/or local). This means that the orientation of these policies responds to a larger project - national agenda capable of determining the material and institutional basis of the development process of the nation and its parts. Therefore, the development of localities can only be sustained if it is centered on a social project very well structured according to the national question itself.

The problem is that the national question remains unresolved. After a long ostracism, there was a strong expectation that a center-left government would rescue the national / regional planning. The regional issue reintroduced into the Lula government as a public agenda in 2003 with the launching of the National Policy for Regional Development (PNDR) with a set of policies and programs implemented by the federal government in the period 2003-2010. Participated of the PNDR the Ministries of National Integration (National Policy of Regional Development); Agrarian Development (Territorial Citizenship Program); Social Development and Fight against Hunger (Food Security Territories and Local Development); Development, Industry and Foreign Trade (Permanent Working Group for Local Productive Arrangements) and the National Bank for Economic and Social Development (Promotion of Regional Policy and Policy Support for Local Productive Arrangements and Local Development). At the beginning of President Dilma Rousseff's administration, it is possible to see that multiplicity has not only continued as it accentuated, in view of the launching of new related programs.

However, the PNDR has hampered by a series of structural and conjuncture obstacles, including institutional competition for a new generation of territorially oriented programs at the three levels of government, designed according to their own logic and specific audiences, without dialogue with each other.

According to Karam (2012), there was a great disarticulation between the initiatives, with overlapping of target audiences and scales of intervention, conflicts of interest, redundancy of actions, the absence of common agenda, and generalized organizational weaknesses. The degree of fragmentation detected suggests that government action is unlikely to succeed in reducing regional / territorial disparities as intended, especially in light of the lack of institutions capable of mediating the present tensions. Araújo (2011) points out the heterogeneity and amplitude of the electoral coalitions as serious complications for the coordination of policies in the three levels of government, since the occupation of positions in the administrative machine by groups endowed with programmatic orientations and distinct, if not antagonistic, interests, often exacerbates the disarticulation of public action. In the case of the PNDR, negotiation efforts in politically fragmented environments have resulted in a trade-off between governable and governance, given that priorities and deadlines have had to adjust in order to deal with the distribution of power in organs and entities involved in the implementation of the policy. In realities such as this, it can be concluded that there is still a risk that the efforts for better articulation will prove useless if the sector interlocutors follow a strange agenda to the core of the Executive.

At the launch of the second generation of policies for APLs in 2012, by the Thematic Committee of APLs, there is the recognition that:

i) Methodological formulations have not been further developed, neither the concept nor its constituent elements;

ii) Crystallized the vision of local productive arrangements as a separate strategy, lacking, in many cases, convergence with the other policies of the Federal Government and the directives of action of non-governmental institutions; 
iii) The process of staff training to account for the complexity of the development process of the APLs was interrupted;

iv) It was characterized by compensatory actions, often punctual, monoscale, sectorial, and, generally, decontextualized. Traditional policies, oriented by instruments of support to isolated companies in the APLs - more of the same with a new label (SECOND GENERATION OF POLICIES FOR APLs, 2012, p. 4).

Faced with this fragmentation of APL policies, Cassiolato (2012) makes a distinction between the new generation of "policies for APL", while in the first generation it was "policies in APL". The author draws attention in the new policy that the actions and the instruments have as a presupposition the systemic development of APLs. Advancing this second generation concept, Lastres (2011) points out the opportunities for the development of Brazil with the use of a systemic policy capable of mobilizing and welcoming the demands of the different territories in all their diversity. This implies integrating national, regional, state and local development priorities into a long-term perspective.

Based on these assumptions made by Cassiolato (2012) and Lastres (2011), the new generation of APLs presents the following objectives: 1) income generation and poverty reduction; 2) assimilation and incorporation of knowledge and innovation (learning, cooperation); 3) sustainability; 4) restructuring of spaces, through the incorporation of forgotten regions, so-called policy gaps; 5) ability to mobilize systemic processes, emphasizing the systemic articulation as an element of coordination rather than a generalized rhetoric about governance.

Therefore, there is a proposal coordinated by RedeSist that suggests that as a normative guideline the declarative criteria for determining the scope of policies should be those established by the social and productive policy strategy in the sphere of the federal government. This signals a policy of APLs as an articulated element of the national development policy. Thus, APL policies should be conditioned to the strategic macro-axes contemplated in the Greater Brazil Plan (PBM), the Brazil Without Misery Plan (PBSM) and the National Policy for Regional Development (PNDR), which deal with innovation, income welfare of the population, especially the productive inclusion and reducing regional inequalities in the country. Therefore, there is a need to make a special snippet in these action plans in order to map how they work innovation, productive inclusion, and territorial development, which are the structuring axes of a policy for APL.

In the National Plan of Regional Development, a large amount of planning and management actions are proposed with a potential focus on combating regional inequalities, aiming to reach the territory. They range from rural development and irrigation to support for local productive arrangements, local innovation systems, and export ventures. In the first National Conference of Regional Development, coordinated by the Ministry of National Integration, with the theme Regional Development for National Integration, in 2013, the reference document presented portrays the production of a series of specific advances in the spaces and APLs supported. However, important limitations were identified:

i) A few resources were very low and with a high participation of parliamentary amendments, which are limited in relation to the objectives of the programs;

ii) The actions were, as a rule, punctual, diffuse and without continuity, with a low capacity to transform regional dynamics. Its application within the scope of the PNDR has often lapsed into a localist vision, translating into fragmented actions and with a much more compensatory social policy than local and regional socioeconomic development;

iii) The actions of these Programs were not articulated with the funds and incentives, the instruments of greater breath available for the policy. Thus, enterprises attracted and / or promoted with funding and incentives were not selected accordingly to consolidate the strategic productive 
arrangements and chains of those regions. On the other hand, the actions and support to the APLs are not oriented by the effort to strengthen the regional systems and chains, or also, the integration between the great structuring investments and the local economy;

iv) The low articulation of the programs with the actions of the States. The very structure of PROMESO, and other programs favored the direct relationship of the federal government with the local authorities, without going through an articulation with the state governments, representing great losses, not only with regard to the possibilities of synergy between actions but also in the political legitimation of PNDR;

v) A limited integration with the other territorial-based federal programs and with the other areas of the Integration Ministry, in addition to its affiliated companies. (NATIONAL CONFERENCE ON REGIONAL DEVELOPMENT, 2013, p.23-24)

At this point, there is an effort by the federal government, through working groups, to develop articulated actions to minimize the overlap and absence of joint and / or complementary actions in PBM, PBSM, and PNDR. Despite setting a work in progress with practical results still incipient, this movement signals an important inflection. It is necessary to consider the concrete limits of a strategy that proposes the implementation of a model of microregional emphasis and notably captained by segments traditionally deprived of both power resources and permanent connections with dynamic sectors and national and international decision-making centers. In other words, ignoring the complex set of forces inherent in the globalization movement can subvert the objective of a new model of sustainable and autonomous development, reproducing the misconceptions of localistic views doomed to failure.

In the case of the Permanent Working Group to Support Local Productive Arrangements (GTP APL), there is a double interest permeating the initiative of the federal government to establish guidelines for the work of its organs in supporting APL. There is an unprecedented effort of federative interlocution on the theme, of reorientation with the policies of second generation of APLs, strongly supported by an epistemic community of neoschumpeterian focus, in which Redesist stands out. However, in spite of the fact that the APLs constitute a promising instrument of economic policy, and once there are numerous programs and actions at both the federal and state levels, it is possible to observe that there is still a wide disorganization of the public sphere in Brazil, the delimitation and operation of public policies to support the development of these agglomerates, which is reflected in the low number of consolidated APLs in the country. In other words, the various public actions have not been able to positively impact the development of productive arrangements, and there is a feeling of lack of effective, agreed and articulated public policies on the part of society and the members of the majority of the agglomerations.

This also applies to the work of the GTP APL in identifying, diagnosing, classifying, and implementing development support policies in the selected APLs. In fact, it is a work in progress. However, it is a sine qua non that agglomerates build centripetal forces beneficial to the development of local social capital, local governance capacity, and regional economic development. Clearly, a research agenda is open that deepens the potential impacts caused by second generation of APL policies on regional development.

Without a broad organization of the public sphere with regard to the design and operation of public policies to support the development of these arrangements, with the effective participation of the academic community and organized productive segments of society, it will hardly have a consolidated policy of second generation of APLs in Brazil. Without this policy, productive arrangements will continue, theoretically, as instruments of territorial planning and regional integration. Practically, regional fragmentation and fraying of the federative space remain. This is an extremely relevant topic in a country like Brazil characterized by strong regional inequalities and with the PNDR built and operated by conflicting agendas of interests. 


\section{FINAL CONSIDERATIONS}

In this paper, the possibility of regional development was evaluated, having as reference the policy of local productive arrangements. As a starting point for the analysis, there are significant changes in the structuring and conceptualization of the APLs in which a theoretical effort noted in academia, governments and productive segments in the implementation of science, technology and innovation policy in Brazil. The role in the APLs policy formulation strengthened in order to reduce regional inequalities and, thus, the technological backwardness of the country. In this direction, there is a very special work of the GTP APL to strengthen the connections between the instances of policy formulation, the scientific-technological base, and the business sector.

In the analysis of the diverse experiences of the APLs policy in Brazil in the last decades, it is noticed an advance in the use of a conceptual methodological base built in the academic sphere and used concretely for the regional development. This base has made it possible to carry out actions in heterogeneous contexts and realities from a productive, territorial and social point of view, as in the case of the policies implemented by the APLs in the different units of the Federation.

As a lesson learned, it understood that the conceptual basis initially used by local productive arrangements in its first generation in Brazil served to identify concrete problems that must be faced by the formulators of this arrangement policy. In spite of all the conceptual advances of the APLs, the demand for a more consolidated systematization from the conceptual and political point of view in the formulation and implementation of regional and local development policies as in the present case must be in appreciation. In this regard, the work of communities of experts from the academic sphere, thematic groups, advisory councils articulated to the GTP APL and its regional centers signaled a new look at this new proposal for second generation policies for APLs.

In this direction, a very positive expectation was outlined with the second generation of policies for APLs in order to allow appropriate adjustments between the academic world, public policymakers and the productive segments of society. This evolutionary capacity of generations of policies, of adjustment of all the actions implemented so far in the policy of APLs, can be a genuine process of learning a policy of a true systemic interaction between its entities that promotes the strengthening of productive and innovative capacities, regional and local development.

\section{BIBLIOGRAPHIC REFERENCES}

AFFONSO, Rui de Britto Álvares e Pedro Luiz Barros Silva. A federação em perspectiva: ensaios selecionados. Edições Fundap, 1995.

APOLINÁRIO, Valdênia; SILVA, Maria Lussieu da. Análise das políticas para arranjos produtivos locais no Norte, Nordeste e Mato Grosso. In: APOLINÁRIO, Valdênia; SILVA, Maria Lussieu da. (orgs.) Políticas para arranjos produtivos locais. Análise em estados do Nordeste e Amazônia Legal. Natal: EDUFRN, 2010.

ARAÚJO, Tânia Bacelar de. Brasil: Contexto atual e desafios para o Ministério da Integração. Texto apresentado no seminário de planejamento estratégico do Ministério da Integração. Brasília: abril de 2011.

BANCO MUNDIAL. Entering the 21st century. World Development Report 1999-2000. Washington (DC): The World Bank, 2000.

BRANDÃO, Carlos. A dimensão espacial do subdesenvolvimento. Campinas, 2003. Teses (Livre Docência) - UNICAMP/IE.

BRANDÃO, Carlos. A busca da utopia do planejamento regional. Revista Paranaense de Desenvolvimento. Curitiba, no 20 , p. 17-37, jan./jun. 2011.

BRANDÃO, Carlos. Território e desenvolvimento: as múltiplas escolhas entre o local e o global. Campinas: Ed. UNICAMP, 2007. 
BRASIL. Ministério do Planejamento, Orçamento e Gestão. Planos do Governo Federal (PPA 2004-2007; PPA 2008-2011). Disponível em http://www.planejamento.gov.br/ministerio.asp?index=10\&ler=s1086\#\#p paAntigos. Acesso em: 20 fev. 2015.

CAMPOS, R. R. et ali (org). Políticas estaduais para arranjos produtivos locais no Sul, Sudeste e Centro-Oeste do Brasil. Rio de Janeiro: e-papers, 2010.

CAPORALI, R. A Política de APLs no Brasil: uma breve análise de origens, evolução e desafios, apresentado no Painel: O papel dos clusters no desenvolvimento regional: perspectiva do Brasil In: Congresso Latino- Americano de Clusters. Minas Gerais - Ouro Preto, 18/5/2011.

CASsiolato, J. E. Análise das Políticas de APLs no Brasil. Por uma nova geração de políticas para APLs. Brasília: Seminário, 2012. (Mimeografado).

CASSIOLATO, J. E.; LASTRES, H.M.M. (org.). Globalização e inovação localizada: experiências de sistemas locais no Mercosul. Brasília: IBICT/MCT, 1999.

CASSIOLATO, J. E.. Novas políticas na era do conhecimento. Rio de Janeiro: IE/UFRJ, 2003.

CASTELLS, M. A Sociedade em rede. São Paulo: Paz e Terra, 1999.

CHESNAIS, F. A Mundialização do capital. São Paulo: Xamã, 1996.

Conferência Nacional de Desenvolvimento Regional. Brasília: Ministério da Integração Nacional, 2013. CORÒ, Giancarlo. Distritos e sistemas de pequena empresa em transição. In: COCCO, G. et al. Empresários e empregos nos nossos territórios produtivos: o caso da terceira Itália. Rio de Janeiro: DP\&A, 2002. COSTA, Eduardo José Monteiro. Arranjos produtivos locais, políticas públicas e desenvolvimento regional. Brasília: Mais Gráfica Editora, 2010.

FREEMAN, C. Technology policy and economic performance. London: Pinter, 1987.

HAAS, Peter. Introduction: epistemic communities and international policy coordination. In: HAAS, Peter (ed.). Knowledge, power and international coordination. University of South Carolina Press, 1997

JOHNSON, B.; LUNDVALL, B. A. Why all this fuss about codified and tacit knowledge? In: The Druid Winter Conference. 18-20 Jan. 2001. Aalborg, 2001.

KARAM, Ricardo Antônio de Sousa. A economia política do desenvolvimento territorial. Rio de Janeiro, 2012. Tese doutorado. UFRJ/Instituto de Economia.

LASTRES, H. M.M. O novo ciclo de desenvolvimento e a política para APLs. $5^{\text {a }}$ Conferência Brasileira de Arranjos Produtivos Locais, Brasília, 9/11/2011 (Mimeografado).

LASTRES, Helena M. M.; CASSIOLATO, José Eduardo. Novas políticas na era do conhecimento. Rio de Janeiro: IE/UFRJ, 2003.

LASTRES, H. M.M. Arranjos e sistemas produtivos e inovativos locais: contribuições para uma nova política de desenvolvimento industrial e tecnológico. Estudo para subsidiar a abordagem da dimensão territorial do desenvolvimento nacional no Plano Plurianual de Ação 2008-2011 e no planejamento governamental de longo prazo. CGEE, MCT, 2007

LASTRES, H. M.M. Arranjos Produtivos e Inovativos Locais: contribuições para uma nova política de desenvolvimento industrial e tecnológico. Brasília: Ministério da Integração Nacional, Boletim Regional $\mathrm{n}^{\mathrm{o}}$ 7, maio-agosto de 2008.

LASTRES, H. M.M. et al. O apoio ao desenvolvimento regional e aos arranjos produtivos locais. In: Alem, A. C.; Giambiagi, F. (org.). O BNDES em um Brasil em transição. Rio de Janeiro: BNDES, 2010.

LUNDVALL, B. Innovation as an interactive process: from user-producer interaction to the National Innovation Systems. In: DOSI, G. et al. (Eds.). Technical change and economic theory. London: Pinter, 1988. MARSHALL, A. Princípios de economia. São Paulo: Nova Cultural, 1985.

MINISTÉRIO DE DESENVOLVIMENTO, INDÚSTRIA E COMÉRCIO. $\mathbf{2}^{\mathbf{a}}$ geração de políticas para APLs. Brasília: 2012.

NELSON, R. R. National innovation systems: a comparative analysis. New York - Oxford: Oxford University Press, 1983.

PORTER, M.E. The competitive advantage of nations. London: Macmillan press, 1986. 
VIEIRA, J. C.

RedeSist/BNDES. Políticas estaduais para arranjos produtivos locais no Sul, Sudeste e Centro-Oeste do Brasil. Rio de Janeiro: e-papers, 2010.

SCHMITZ, H. Aglomerações produtivas locais e cadeias de valor: como a organização das relações entre as empresas influência o aprimoramento produtivo. In: LASTRES, H; CASSIOLATO, J.; ARROIO, A. (orgs.) Conhecimento, sistemas de inovação e desenvolvimento. Rio de Janeiro: Editora UFRJ/Contraponto, 2005. SCHUMPETER, J.A. Teoria do desenvolvimento econômico. São Paulo: Abril Cultural, 1982.

STORPER, M. The regional world: territorial development in a global economy. New York: Guilford, 1997. 